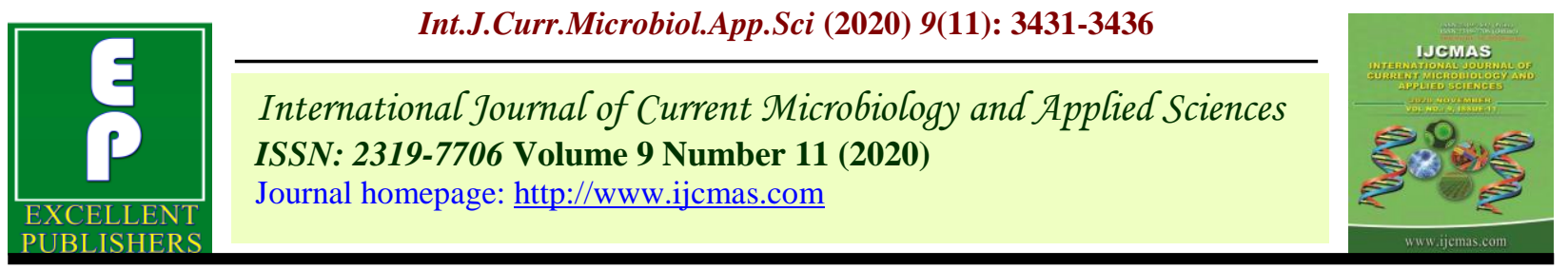

\title{
Study of Phenological Parameters and Agrometeorological Indices of Indian Mustard (Brassica juncea L. Czern) Varieties under Different Sowing Dates
}

\author{
Surabhi Bhardwaj", N. S. Solanki and Chetana Nagar
}

Department of Agronomy, Rajasthan College of Agriculture, Maharana Pratap University of Agriculture and Technology (MPUAT), Udaipur, Rajasthan, India

*Corresponding author

\begin{abstract}
A B S T R A C T
Keywords

Brassica juncea, phenology, Agrometeorological indices, Sowing dates, Indian mustard, PAR interception

Article Info

Accepted:

24 October 2020

Available Online:

10 November 2020

A field experiment was conducted at Udaipur during the 2019-20 Rabi season to assess the effect of sowing dates and varieties on phenology and agrometeorological indices of mustard. The experiment consisted of three dates of sowing $\left(\mathrm{D}_{1}-21^{\text {st }}\right.$ October, $\mathrm{D}_{2}-1^{\text {st }}$ November and $\mathrm{D}_{3}-16^{\text {th }}$ November $)$ as main plot treatments and sub-plot treatments consisted of five varieties $\left(\mathrm{V}_{1^{-}}\right.$Bio-902, $\mathrm{V}_{2^{-}}$ Giriraj, $\mathrm{V}_{3}-\mathrm{RH}-0749, \mathrm{~V}_{4}-\mathrm{NRCHB}-101$ and $\mathrm{V}_{5}$ - NRCDR-2) in a split plot design. The results revealed that crop sown on $21^{\text {st }}$ October registered longest crop duration as compared to $1^{\text {st }}$ November and $16^{\text {th }}$ November sown crop. Among varieties RH-0749 recorded longest crop duration followed by NRCDR-2 and Bio902, Giriraj and NRCHB-101. Among agrometeorological indices GDD for physiological maturity and HUE was higher for $21^{\text {st }}$ October sown crop followed by $1^{\text {st }}$ November and $16^{\text {th }}$ November sown crop. Among varieties, RH-0749 accumulated maximum GDD. Highest HUE was recorded by variety NRCHB-101 and NRCDR-2.
\end{abstract}

\section{Introduction}

India is third largest producer $(11.3 \%)$ of oilseed brassica after Canada and China in the world (Jat et al., 2019). In our country, rapeseed-mustard contributes 28.6 percent of the total oilseeds production and ranks second after groundnut sharing 27.8 percent in the India's oilseed economy (Shekhawat et al., 2012). Rapeseed-mustard crop occupies an area of 6.23 million ha in India with production and productivity of 9.34 million tonnes and $1499 \mathrm{~kg} / \mathrm{ha}$, respectively
(Government of India, 2018-19). Major rapeseed- mustard producing states are Rajasthan, Uttar Pradesh, M.P, Haryana, Punjab, Assam, Bihar, Gujarat and West Bengal. Rajasthan is one of the highest oilseeds producing states in India. It occupies first position in area and production of mustard in the country. It accounts for an area of 2.76 million ha with production of 4.81 million tonnes and productivity of $1740 \mathrm{~kg} / \mathrm{ha}$ (Government of Rajasthan, 2018-19). Indian mustard belongs to family Cruciferae, genus Brassica and species juncea. Rapeseed is 
locally known as sarson, toria, yellow toria while mustard is named 'rai' or 'laha'. Mustard is a winter season crop and its physiological and morphological development is markedly influenced by weather conditions. Weather is one of the key factors affecting its production and productivity. In spite of cultivation of high yielding varieties, enhanced cultural practices and plant protection measures, favourable weather is a necessity for good harvest (Rao et al., 1999). The time of sowing is very important for mustard production (Mondal et al., 1999). Environmental conditions have a direct bearing on crop phenological development and total biomass production. Phenological variations are mainly due to photoperiod and temperature changes which affect some plant structures (e.g. Number of leaf primordia and rate of leaf emergence), critical for crop phenology (Miralles et al., 2001). In general, increase in temperature and day length leads to shortening in the maturity phase (Robertson et al., 2002). Late sowing of mustard crop may lead to reduction in the maturity period by 25 to 30 days, mainly due to fast accumulation of growing degree days (GDD) which is essentially required in crops for completion of their life cycles (Adak et al., 2011).

The agrometeorological indices, GDD and heat use efficiency (HUE) help in predicting phenophases and crop yield. GDD or heat units assumes direct and linear relationship between growth of plants and temperature. The computation of HUE helps in evaluation of yield potential of different crops in different environments (Kumari et al., 2009 and Tyagi, 2014). The optimization of sowing time and selection of high yielding varieties through research on phenology and agrometeorological indices is prerequisite to boost the growth and yield of the crop (Kumar et al., 2017).

\section{Materials and Methods}

The experiment was conducted during Rabi season of 2019-2020 at the Instructional Farm, Rajasthan College of Agriculture, Udaipur. The site is situated at South-Eastern part of Rajasthan at an altitude of $582.2 \mathrm{~m}$ above mean sea level, $24^{\circ} 35^{\prime} \mathrm{N}$ latitude and $73^{\circ} 42^{\prime}$ E longitude. The mean annual rainfall of the region is $600.8 \mathrm{~mm}$, most of which is contributed by south west monsoon from June to September. The soil of experimental field was clay loam in texture and slightly alkaline in reaction. The experiment consisted of 15 treatment combinations with three dates of sowing $\left(16^{\text {th }}\right.$ October, $1^{\text {st }}$ November and $16^{\text {th }}$ November) and five mustard varieties (Bio902, Giriraj, RH-0749, NRCHB-101 and NRCDR-2). The experiment was laid out in split plot design with four replications. The phenological data comprising number of days required for completion of emergence, fifth leaf stage, bud initiation, first flower opening, 50 per cent flowering, lowest pod greater than $2 \mathrm{~cm}$ long and physiological maturity. The GDD were calculated as the difference between the daily mean temperature and threshold temperature (Nuttonson, 1955).

$\mathrm{GDD}=\frac{\text { (Max temperature }+ \text { Min. temperature) }}{2}-$ Threshold temperature

Threshold temperature of $5^{\circ} \mathrm{C}$ was considered for mustard crop. Heat unit efficiency for grain and biological yields was calculated as (Pandey et al., 2010).

$$
\operatorname{HUE}\left(\mathrm{kg} \mathrm{ha} \mathrm{a}^{-1}{ }^{\circ} \mathrm{C} \text { day }\right)=\frac{\text { Seed or stover yield }\left(\mathrm{kg} \mathrm{ha}^{-1}\right)}{\operatorname{GDD}\left({ }^{\circ} \mathrm{CDay}\right)}
$$

Photosynthetically active radiation (PAR) was recorded at 55 and 75 days after sowing at hourly interval from 11.00 to 15.00 hours. The incident PAR was measured by facing the ceptometer sky wards above the canopy. The transmitted PAR (TPAR) was measured by 
placing the ceptometer on the ground. Both the readings were taken first standing in East direction then in West. The intercepted PAR (IPAR \%) was calculated by using formula:

$\operatorname{IPAR}\left(\mu\right.$ mole $\left.\mathrm{m}^{-2} \mathrm{~s}^{-1}\right)=$ PAR above canopyPAR below canopy

$\operatorname{IPAR}(\%)=\frac{\text { IPAR }}{\text { PAR above canopy }} \times 100$

\section{Results and Discussion}

\section{Phenological stages}

Different sowing dates had a significant effect on various phenological stages of plant and the agrometeorological indices as presented in Table 1 and Table 2. $16^{\text {th }}$ November sown crop took maximum number of days to attain emergence (4.5), fifth leaf stage (15.4), bud initiation (38.5), first flower opened (47.9), $50 \%$ flowering (53.0) and lower pod $>2 \mathrm{~cm}$ long (60.2) as compared to $1^{\text {st }}$ November and $16^{\text {th }}$ October sown crops. However, $16^{\text {th }}$ October sown crop took maximum days to attain physiological maturity (126.7) while minimum days (116.3) were taken by $16^{\text {th }}$ November sown crop. In late sown crop, the overall duration was reduced with shorter reproductive phase. Higher temperature coupled with low relative humidity at reproductive phase, resulted into forced maturity in late sown crops and reduced crop duration. In general, increase in temperature, sunshine hours and day length leads to shortening in the maturity phase. Similar results were obtained by Robertson et al., (2002) and Kaur et al., (2018).

Variety RH-0749 took higher number of days (123.1) to attain various stages viz., emergence (4.4), fifth leaf stage (14.8), bud initiation (39.4), first flower opened (48.7), $50 \%$ flowering (54.0), lower pod> $2 \mathrm{~cm}$ (60.3) and physiological maturity (123.1). This variation among varieties can be attributed to their genetic makeup. This is well supported by Adak et al., (2011) and Kumar et al., (2018) (Table 3).

Table.1 Effect of sowing dates and varieties on days required to attain different phenological stages of mustard

\begin{tabular}{|l|c|c|c|c|c|c|c|}
\hline \multicolumn{1}{|c|}{ Treatment } & Emergence & $\begin{array}{c}\text { Fifth } \\
\text { leaf } \\
\text { stage }\end{array}$ & $\begin{array}{c}\text { Bud } \\
\text { initiation }\end{array}$ & $\begin{array}{c}\text { First } \\
\text { flower } \\
\text { opened }\end{array}$ & $\begin{array}{c}\text { 50\% } \\
\text { flowering }\end{array}$ & $\begin{array}{c}\text { Lower pod } \\
\text { >2 cm long }\end{array}$ & $\begin{array}{c}\text { Physiological } \\
\text { maturity }\end{array}$ \\
\hline Sowing dates & & & & & & \\
\hline $\mathbf{1 6}^{\text {th October }}$ & 3.6 & 14.0 & 34.6 & 42.1 & 45.9 & 52.0 & 126.7 \\
\hline $\mathbf{1}^{\text {st }}$ November & 4.0 & 14.4 & 35.2 & 42.5 & 47.1 & 52.4 & 122.6 \\
\hline $\mathbf{1 6}^{\text {th }}$ November & 4.5 & 15.4 & 38.5 & 47.9 & 53.0 & 60.2 & 116.3 \\
\hline SEm \pm & 0.18 & 0.27 & 0.47 & 0.42 & 0.30 & 0.27 & 0.56 \\
\hline CD (P= 0.05) & 0.63 & 0.94 & 1.63 & 1.46 & 1.03 & 0.94 & 1.92 \\
\hline Varieties & & & & & & & \\
\hline Bio-902 & 4.0 & 14.7 & 35.4 & 42.6 & 47.2 & 53.3 & 121.3 \\
\hline Giriraj & 4.0 & 14.5 & 34.8 & 42.8 & 47.3 & 53.3 & 121.3 \\
\hline RH-0749 & 4.4 & 14.8 & 39.4 & 48.7 & 54.0 & 60.3 & 123.1 \\
\hline NRCHB-101 & 3.9 & 14.3 & 35.2 & 42.7 & 47.2 & 53.0 & 121.3 \\
\hline NRCDR-2 & 3.7 & 14.5 & 35.6 & 43.9 & 47.6 & 54.4 & 122.2 \\
\hline SEm \pm & 0.23 & 0.21 & 0.36 & 0.37 & 0.36 & 0.29 & 0.40 \\
\hline CD (P=0.05) & NS & NS & 1.00 & 1.04 & 1.00 & 0.82 & 1.12 \\
\hline
\end{tabular}


Table.2 Effect of sowing dates and varieties on growing degree days (GDD) and heat unit efficiency (HUE) of mustard

\begin{tabular}{|c|c|c|c|c|c|c|}
\hline \multirow[t]{2}{*}{ Treatment } & \multicolumn{4}{|c|}{ GDD ( ${ }^{0} \mathrm{C}$ days $)$} & \multicolumn{2}{|c|}{ HUE $\left(\mathrm{kg} / \mathrm{ha} /{ }^{\circ} \mathrm{C}\right.$ day $)$} \\
\hline & Emergence & $\begin{array}{l}\text { Fifth leaf } \\
\text { stage }\end{array}$ & $\begin{array}{l}\text { First flower } \\
\text { opened }\end{array}$ & $\begin{array}{c}\text { Physiological } \\
\text { maturity }\end{array}$ & $\begin{array}{c}\text { On seed } \\
\text { yield basis }\end{array}$ & $\begin{array}{c}\text { On biological } \\
\text { yield basis }\end{array}$ \\
\hline \multicolumn{7}{|l|}{ Sowing dates } \\
\hline $16^{\text {th }}$ October & 58.7 & 242.1 & 682.5 & 1540.6 & 1.1 & 4.6 \\
\hline $1^{\text {st }}$ November & 73.3 & 252.3 & 624.9 & 1457.4 & 0.9 & 4.3 \\
\hline $16^{\text {th }}$ November & 63.7 & 227.3 & 549.5 & 1314.0 & 0.8 & 4.4 \\
\hline SEm \pm & 3.05 & 4.49 & 3.94 & 7.64 & 0.02 & 0.03 \\
\hline $\mathrm{CD}(\mathrm{P}=0.05)$ & 10.56 & 15.54 & 13.63 & 26.43 & 0.08 & 0.11 \\
\hline \multicolumn{7}{|l|}{ Varieties } \\
\hline Bio-902 & 65.1 & 242.3 & 602.4 & 1429.2 & 0.9 & 4.4 \\
\hline Giriraj & 65.1 & 239.3 & 604.4 & 1430.0 & 0.9 & 4.4 \\
\hline RH-0749 & 71.9 & 244.5 & 665.1 & 1455.6 & 0.8 & 4.0 \\
\hline NRCHB-101 & 64.1 & 236.9 & 604.3 & 1429.0 & 1.0 & 4.6 \\
\hline NRCDR-2 & 59.9 & 239.9 & 618.7 & 1442.0 & 1.0 & 4.6 \\
\hline SEm \pm & 3.71 & 3.49 & 4.59 & 5.75 & 0.02 & 0.03 \\
\hline $\mathrm{CD}(\mathrm{P}=\mathbf{0 . 0 5})$ & NS & NS & 12.71 & 15.92 & 0.05 & 0.08 \\
\hline
\end{tabular}

Table.3 Effect of sowing dates and varieties on intercepted photosynthetic active radiation (IPAR) of mustard

\begin{tabular}{|c|c|c|c|c|}
\hline \multirow[t]{2}{*}{ Treatments } & \multicolumn{2}{|c|}{$\operatorname{PAR}\left(\mu\right.$ mole $\left.m^{-2} s^{-1}\right)$} & \multicolumn{2}{|c|}{$\operatorname{IPAR}(\%)$} \\
\hline & 55 DAS & 75 DAS & 55 DAS & 75 DAS \\
\hline \multicolumn{5}{|l|}{ Sowing dates } \\
\hline $16^{\text {th }}$ October & 803.4 & 856.7 & 95.0 & 97.9 \\
\hline $1^{\text {st }}$ November & 799.2 & 852.0 & 94.8 & 96.9 \\
\hline $16^{\text {th }}$ November & 707.3 & 788.7 & 91.6 & 95.1 \\
\hline \multicolumn{5}{|l|}{ Varieties } \\
\hline Bio-902 & 755.2 & 841.4 & 93.8 & 97.0 \\
\hline Giriraj & 775.8 & 826.9 & 93.9 & 96.8 \\
\hline RH-0749 & 765.4 & 818.1 & 93.8 & 97.3 \\
\hline NRCHB-101 & 776.6 & 833.3 & 92.8 & 97.4 \\
\hline NRCDR-2 & 776.9 & 842.7 & 94.6 & 97.9 \\
\hline
\end{tabular}

\section{Agrometeorological indices}

Growing degree days (GDD), heat use efficiency (HUE) and PAR interception (\%) at 55 and 75 DAS were critically observed at three sowing dates. Highest GDD at maturity $\left(1540.6{ }^{0} \mathrm{C}\right.$ day) was accumulated by $16^{\text {th }}$
October sown crop while lowest GDD (1314 ${ }^{0} \mathrm{C}$ day) was accumulated by $16^{\text {th }}$ November sown crop. The growing degree days observed a declining trend with successive delay in sowing. These results are in close conformity with the findings of Neog and Chakravarty (2005) and Solanki and Mundra 
(2015). Maximum HUE for seed yield basis $\left(1.1 \mathrm{~kg} / \mathrm{ha} /{ }^{0} \mathrm{C}\right.$ day) and PAR interception $(\%)$ (95.0 and $97.9 \%$ ) at 55 and 75 DAS, respectively were recorded under $16^{\text {th }}$ October sowing. This could be ascribed as the result of declined dry matter production as both radiation interception and HUE shares direct and linear relationship with dry matter accumulation. Further, lesser growing degree days accumulation by the delayed sown crops also leads to lesser HUE. Similar results were obtained by Tyagi (2017) and Jain and Sandhu (2019).

Among varieties, RH-0749 accumulated maximum GDD at physiological maturity $\left(1455.6{ }^{0} \mathrm{C}\right.$ day) which was significantly higher over other varieties. This might be due to longer growth duration in var. RH-0749. Higher value of HUE for seed yield basis was reported by var. NRCDR-2 and NRCHB-101 $\left(1.0 \mathrm{~kg} / \mathrm{ha} /{ }^{\circ} \mathrm{C}\right.$ day) as compared to other varieties. Further, higher value of PAR interception (\%) (94.6 and $97.9 \%$ ) was recorded by var. NRCDR-2 at 55 and 75 DAS, respectively. This discrepancy in agrometeorological indices can be ascribed to the genetic behaviour of respective varieties. The similar contentions were given by Srivastava et al., (2011), Neog et al., (2013) and Gupta et al., (2017).

\section{References}

Adak, T., Chakravarty, N. V. K., Muthukumar, M., Deshmukh, P. S., Joshi, H. C. and Katiyar, R. K. 2011. Evaluation of biomass and thermal energy utilization efficiency of oilseed Brassica (Brassica juncea) under altered micro-environments. Biomass bioenergy, 35: 2254-2267.

Government of India. 2018-19. Directorate of Economics and Statistics, Ministry of Agriculture and Farmers Welfare, government of India. https://eands.dacnet.nic.in/

Government of Rajasthan. 2018-19. Fourth Advance Estimate. Commisionerate of Agriculture, Rajasthan- Jaipur.

Gupta, M., Sharma, C., Sharma, R., Gupta, V. and Khushu, M. K. 2017. Effect of sowing time on productivity and thermal utilization of mustard (Brassica juncea) under sub-tropical irrigated conditions of Jammu. Journal of Agrometeorology, 19: 137-141.

Jat, R. S., Singh, V. V., Sharma, P. and Rai, P. K. 2019. Oilseed brassica in India: demand, supply, policy perspective and future potential. $O C L, 26: 8$.

Jain, G. and Sandhu, S. K. 2019. Radiation interception and growth dynamics in mustard under different dates of sowing. Journal of Pharmacognosy and Phytochemistry, SPI: 499-504.

Kaur, L., Sardana, V. and Sharma, P. 2018. Effect of sowing dates and nitrogen application on growth and productivity of canola oilseed rape (Brassica napus). Journal of Oilseed Brassica, 9: 114-121

Kumari, P., Wadood, A., Singh, R. S. and Kumar R. 2009. Response of wheat crop to different thermal regimes under the agroclimatic condition of

Jharkhand. Journal of Agrometeorology, 11: 85-88.

Kumar, Y., Singh, R., Kumar, A. and Dhaka, A. K. 2017. Phenological behaviour of Indian-mustard genotypes under different sowing environments at Hisar. Indian Journal of Ecology, 44: 255-258.

Kumar, A., Lal, M., Kumar, P., Rajkumar and Kumar, J. 2018. Phenological and growth responses of Indian mustard (Brassica juncea L.) genotypes to different sowing dates. International Journal of Current Microbiology and Applied Sciences, 7: 1435-1440.

Miralles, D. J., Ferro, B. C. and Slafer, G. A. 
2001. Developmental responses to sowing date in wheat, barley and rapeseed. Field Crops Research, 71: 211-223.

Mondal, R. L., Biswas, M., Hyder A. M. K. and Akbar, M. A. 1999. Response of rapeseed genotype Dhali to seed rate and seeding date. Bangladesh Journal of Agricultural Research, 24: 83-90.

Neog, P. and Chakravarty, N. V. K. 2005. Thermal time and phenological model for Brassica juncea. Journal of Agrometeorology, 7: 174-181

Neog, P., Sarmah, K. and Rajbongshi, R. 2013. Thermal indices in rapeseed grown in the north bank plain zone of Assam. Journal of Agrometeorology, 15: 174-177.

Nuttonson, M. Y. 1955. Wheat climate relationship and the use of phenology in ascertaining the thermal and photothermal requirements of wheat. American Institute of Crop Ecology. Washington DC, USA. 388 pp.

Pandey, I. B., Pandey, R. K., Dwivedi, D. K. and Singh, R. S. 2010. Phenology, heat unit requirement and yield of wheat (Triticum aestivum) varieties under different crop growing environment. Indian Journal of Agronomy, 80: 136140.

Rao, G. G. S. N., Rao, K., Rao, A. V. R., Ramakrishna, Y. S. and Victor, W. S. 1999. Resource characterization of Drylands: Climate in a Book, Fifty years of Dryland Agricultural Research in India (Eds. H.P. Singh et al.),
CRIDA, Hyderabad.

Robertson, M. J., Holland, J. F., Bambach, R. and Cawthray, S. 2002. Response of canola and Indian mustard to sowing date in risky Australian environments. Australian Journal of Agricultural Research, 53: 1155-1164.

Shekhawat, K., Rathore, S. S., Premi, O. P., Kandpal and Chauhan, J. S. 2012. Advances in agronomic management of Indian mustard (Brassica juncea L.): An overview. International Journal of Agriculture, 1-14.

Solanki, N. S. and Mundra, S. L. 2015. Phenology and productivity of mustard (Brassica juncea L.) under varying sowing environment and irrigation levels. Annals of Agricultural Research, 36: 312-317.

Srivastava, A. K., Adak, T. and Chakravarty, N. V. K. 2011. Quantification of growth and yield of oilseed Brassica using thermal indices under semi-arid environment. Journal of Agrometeorology, 13: 135-140.

Tyagi, P. K. 2014. Thermal requirements, heat use efficiency and plant responses of chick pea (Cicer arietinum L.) cultivars under different environment. Journal of Agrometeorology, 16: 195198.

Tyagi, P. K. 2017. Thermal requirements and heat use efficiency of Indian mustard varieties under different environments. Journal of Agrometeorology, 19: 164166.

\section{How to cite this article:}

Surabhi Bhardwaj, N. S. Solanki and Chetana Nagar. 2020. Study of Phenological Parameters and Agrometeorological Indices of Indian Mustard (Brassica juncea L. Czern) Varieties under Different Sowing Dates. Int.J.Curr.Microbiol.App.Sci. 9(11): 3431-3436.

doi: https://doi.org/10.20546/ijcmas.2020.911.409 